\title{
ArcheoSciences
}

Revue d'archéométrie

33 (suppl.) | 2009

Mémoire du sol, espace des hommes

\section{Archaeological evaluation of alluvial landscapes in Western Maryland, USA}

Timothy J. Horsley and Robert Wall

\section{(2) OpenEdition}

1 Journals

\section{Electronic version}

URL: https://journals.openedition.org/archeosciences/1336

DOI: 10.4000/archeosciences.1336

ISBN: 978-2-7535-1599-4

ISSN: 2104-3728

Publisher

Presses universitaires de Rennes

\section{Printed version}

Date of publication: 30 October 2009

Number of pages: $85-87$

ISBN: 978-2-7535-0943-6

ISSN: 1960-1360

\section{Electronic reference}

Timothy J. Horsley and Robert Wall, "Archaeological evaluation of alluvial landscapes in Western Maryland, USA", ArcheoSciences [Online], 33 (suppl.) | 2009, Online since 30 October 2011, connection on 21 September 2021. URL: http://journals.openedition.org/archeosciences/1336 ; DOI: https:// doi.org/10.4000/archeosciences. 1336 


\title{
Archaeological evaluation of alluvial landscapes in Western Maryland, USA
}

\author{
Timothy J. Horsley* and Robert WALL ${ }^{* *}$
}

Key words: Floodplain, Landscape, Magnetometer, Prehistoric, Settlements.

This poster presents recent results from a geophysical survey being conducted on alluvial terraces adjacent to the North Branch of the Upper Potomac River in Western Maryland, USA (Fig. 1). This area has seen very little systematic archaeological survey; however, a few prehistoric sites have been recorded from surface finds in the vicinity. Floodplain sites represent some of the more valuable archaeological resources in this region, yet workers continue to rely on labour intensive and often inaccurate means of delineating the principal components of these resources. This project is demonstrating how non-invasive geophysical techniques can be applied to locate, map and evaluate buried archaeological sites on floodplain landscapes with a minimum of archaeological excavation.

The North Branch of the Potomac River valley contains a wealth of information on the entire span of western Maryland prehistory (see Wright 1963; Wall and Curry 1992; Wall 2001, 2004). To date, the majority of investigations have focused on the area around the Barton site (18AG3), a multi-component prehistoric and Contact period site that has been the focus of Towson University archaeological field schools since 1993. The Barton complex is comprised of a cluster of archaeological sites situated on two river terraces on the Potomac River's North Branch. The site complex spans a 12,000 year time frame from Paleoindian (Clovis) to early Historic times, i.e. the period of initial European contact with inhabitants of the region. Evidence of the latter

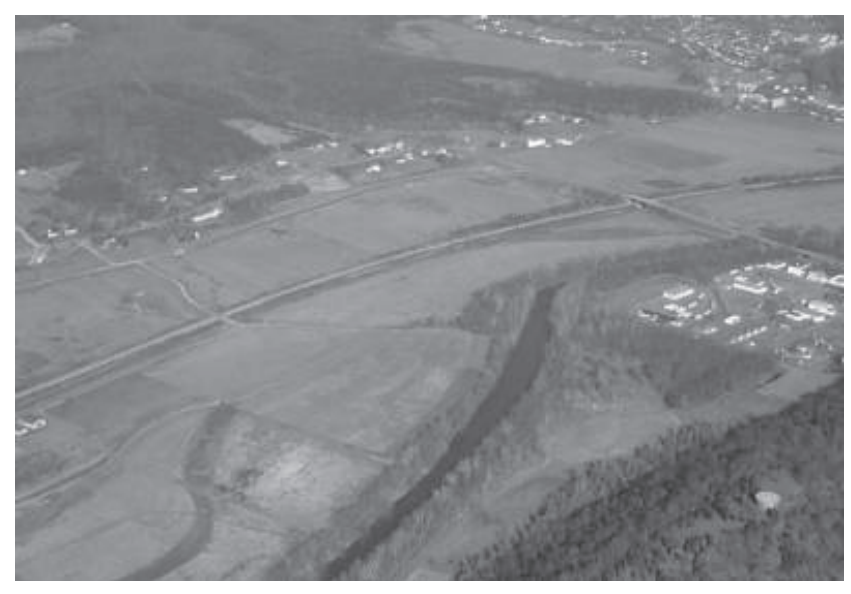

Figure 1: Aerial photograph showing the Upper Potomac River valley in Western Maryland. The Barton Site lies within the field at the centre of the photo between the railway line and the river.

includes finds of European glass trade beads, copper and brass ornaments, and Susquehannock pottery.

Most of this late prehistoric sequence, from ca. AD10001600 , is discernible using geophysical techniques, in particular magnetometry, since these occupations are usually identified at the plough zone-B horizon interface. For example, at the Barton site a circular pattern of dark, organic soil bordered by a palisade trench identifies the Keyser phase (ca. AD1450) occupation; and large bell-shaped pits and

* Museum of Anthropology, The University of Michigan, USA. (timhorsley@gmail.com)

** Department of Sociology, Anthropology and Criminal Justice, Towson University, USA. 
sub-rectangular structures identify Susquehannock occupations. All of these occupations are evident in the distribution of artifacts across the surface of the terrace at Barton. The earliest Late Woodland materials are found at the southern fringe of the site and the most recent artifacts, including European trade goods, are found at the northern end of the site.

Surface finds from throughout this river valley suggest that numerous other Archaic - Contact period settlements existed along the North Branch of the Potomac River. Very little work has been undertaken at the Black Oak area of the valley, $9 \mathrm{~km}$ south of the Barton complex. Based on preliminary landform analysis and soil survey data, the alluvial terrace landscapes at Black Oak appear to have similar stratigraphy to those at the Barton site, and it is likely that similar cultural deposits survive.

Archaeological survey in alluvial floodplain settings has always been problematic because standard archaeological survey techniques are often inadequate for identifying more deeply buried archaeological components. Even for relatively shallow sites, traditional sampling techniques are not well suited to discerning the internal structure of archaeological sites without first conducting extensive excavations. This project aims to assess the potential of geophysical methods for both locating and characterising archaeological sites and features on the floodplain terraces of the Upper Potomac in Western Maryland.

The first phase of this project is investigating the effectiveness of high resolution magnetometer survey for defining archaeological remains at the Barton site. Excavations have revealed features including palisade trenches, pit features, and house structures, all of which produce identifiable magnetic responses. A Bartington Grad601-2 dual fluxgate gradiometer has been employed to collect data at a resolution of $0.5 \mathrm{~m} \times 0.125 \mathrm{~m}$ over the entire 12.5 hectares of the site, and demonstrates the effectiveness of this well-established method for mapping such features (Fig. 2). The results also indicate the complexity in interpreting such data from such a multi-component site: whilst linear features such as palisade trenches are easily recognised, identifying individual structures is more difficult. Magnetic anomalies due to features from multiple periods are superimposed, making it difficult to characterize settlement structure and organisation based on the geophysical data alone. It is also clear that the more deeply buried Paleoindian features, (up to $2 \mathrm{~m}$ ), pose more of a challenge for this method. However, the results are dramatically enhancing the ongoing programme of excavations and are being used to target specific features for investigation with intrusive methods.

Geophysical surveys are also being conducted at the Black Oak area. Due to the size of this area, (ca. 180 hectares), magnetometer surveys have been undertaken within $20 \mathrm{~m}$ wide sample transects at a resolution of $1 \mathrm{~m} \times 0.25 \mathrm{~m}$ to define areas of archaeological interest. These have been followed up with high resolution survey for comparison with the results from the Barton site. In order to better understand the results, test-pits will be excavated over selected areas to evaluate positive and negative findings.
Figure 2: Extract of the magnetometer data collected during 2009. The results indicate three villages enclosed by palisades, superimposed onto a background of anomalies due to earlier and more deeply buried occupation. The broad negative trend in the southern corner coincides with the edge of a terrace.

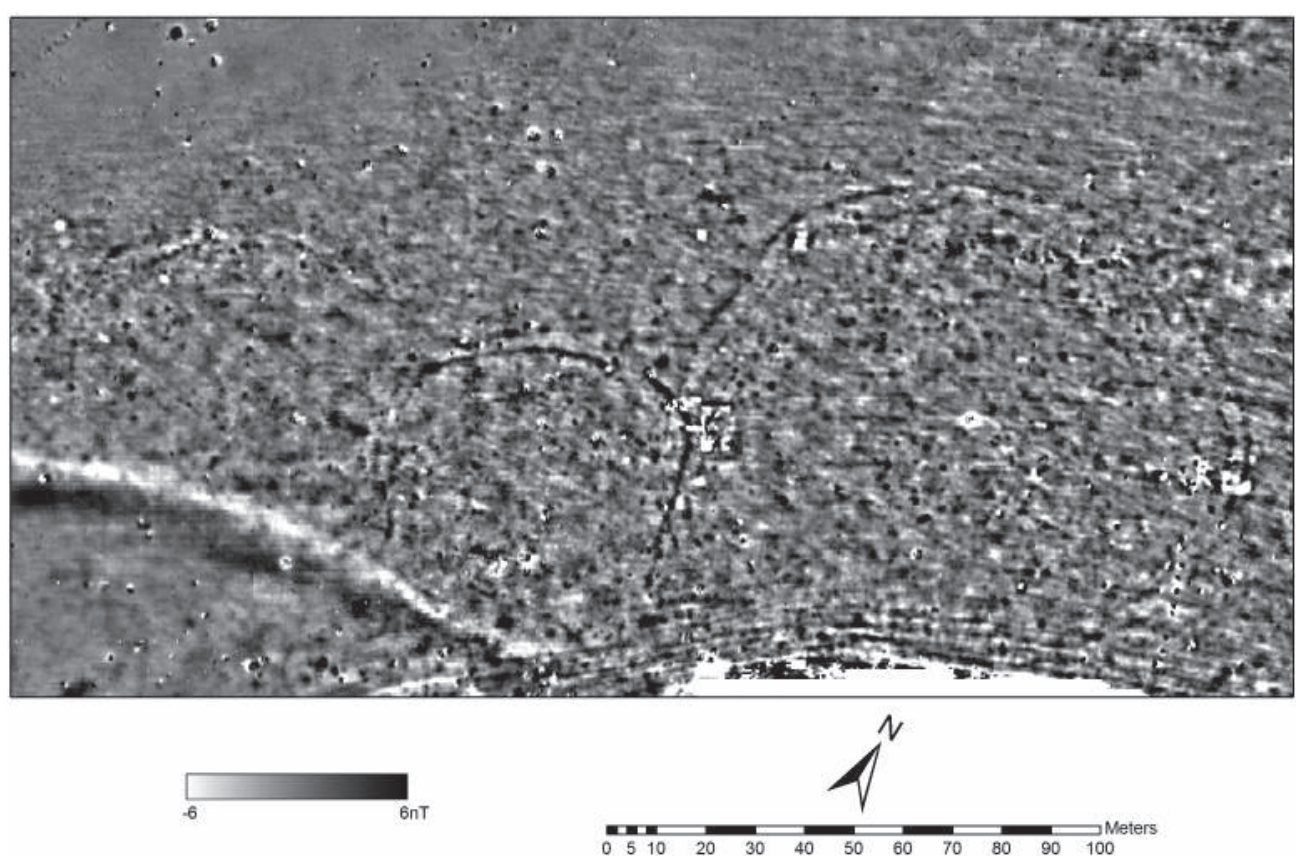


The results of this project are enhancing our understanding of the internal structure and organization of the multi-period remains at the Barton site, as well as illustrating the potential of geophysical methods for alluvial terraces along the Potomac River. It is also hoped that they will help to demonstrate their effectiveness for the non-destructive archaeological evaluation of large areas in North America, a region where geophysical techniques are still generally restricted to small areas on research projects.

The Barton Site is owned by the Archaeological Conservancy and this project is sponsored by the Maryland Historical Trust and Towson State University.

\section{References}

Wall, R. D., 2001. Late Woodland Ceramics and Native Populations of the Upper Potomac Valley. Journal of Middle Atlantic Archaeology, 17: 15-37.

WALL, R. D., 2004. The Chesapeake Hinterlands: Contact Period Archaeology in the Upper Potomac Valley. In Blanton, D., King, J. (dir.). Indian and European Contact in Context: The Mid-Atlantic Region, University Press of Florida, Gainesville, 74-97.

Wall, R. D. and Curry, D., 1992. Test Excavations at the Barton Complex Sites, Allegany County, Maryland. Maryland Archeology, 28(1):13.

Wright, H. T., 1963. The Herman Barton Village Site (18 Ag 3): A Stratified Late Ceramic Site in the Upper Potomac Valley. West Virginia Archeologist, 15:9: 20. 